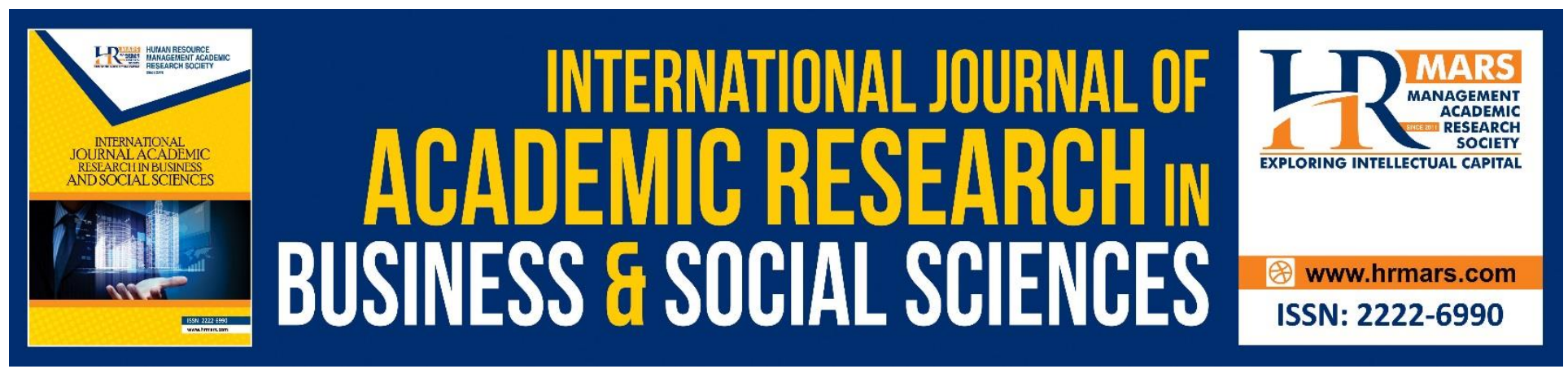

\title{
The Involvement of Religious Organizations in Implementation of Curriculum in Public Secondary Schools in former Western Province of Kenya
}

Amugune A. Aggrey

To Link this Article: http://dx.doi.org/10.6007/IJARBSS/v10-i7/7401

DOI:10.6007/IJARBSS/v10-i7/7401

Received: 16 April 2020, Revised: 05 May 2020, Accepted: 20 June 2020

Published Online: 23 July 2020

In-Text Citation: (Aggrey, 2020)

To Cite this Article: Aggrey, A. A. (2020). The Involvement of Religious Organizations in Implementation of Curriculum in Public Secondary Schools in former Western Province of Kenya. International Journal of Academic Research in Business and Social Sciences, 10(7), 130-149.

Copyright: (C) 2020 The Author(s)

Published by Human Resource Management Academic Research Society (www.hrmars.com)

This article is published under the Creative Commons Attribution (CC BY 4.0) license. Anyone may reproduce, distribute, translate and create derivative works of this article (for both commercial and non-commercial purposes), subject to full attribution to the original publication and authors. The full terms of this license may be seen

at: http://creativecommons.org/licences/by/4.0/legalcode

Vol. 10, No. 7, 2020, Pg. 130 - 149

http://hrmars.com/index.php/pages/detail/IJARBSS

JOURNAL HOMEPAGE

Full Terms \& Conditions of access and use can be found at http://hrmars.com/index.php/pages/detail/publication-ethics 


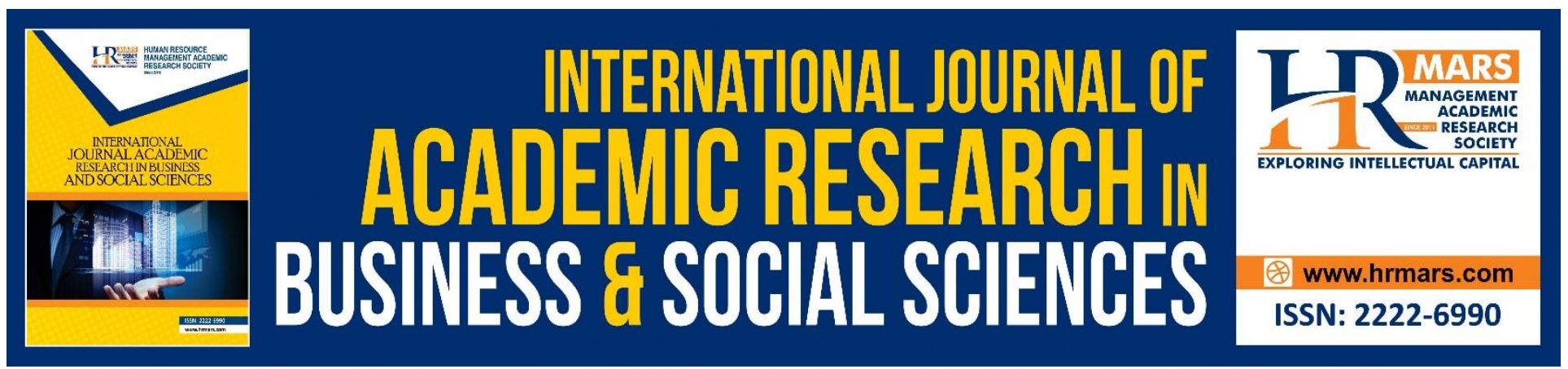

\title{
The Involvement of Religious Organizations in Implementation of Curriculum in Public Secondary Schools in former Western Province of Kenya
}

\author{
Amugune A. Aggrey (PhD) \\ Lecturer at Kaimosi Friends University College-Kenya, Department of Curriculum and Instruction \\ Email: amuguneaggrey66@gmail.com
}

\section{Abstract}

The involvement of religious organizations in implementation of curriculum in public secondary schools informer Western province of Kenya has been viewed as either substantial and meaningful or little by curriculum stakeholders. Indeed the first secondary schools in colonial Kenya were established by Christian missionaries. The constitution of Kenya (2010), the Basic Education Act (2013) and vision 2030 guarantees all children the right to education, free and compulsory basic education. The objective of the study was to find out the involvement of religious organizations in the implementation of curriculum in public secondary schools in former Western province of Kenya. The study was conducted in Bungoma, Busia, Kakamega and Vihiga counties of Western region of Kenya. The study is based on Ludwig Von Bertalanffy Theory of General Systems from which the Systems Approach in the learning process is derived. The study adopted a descriptive survey design. The population for this study was public secondary schools in the region of study. The target population included: County Directors of Education, Sub-County Education Officers, principals and teachers in public secondary schools, religious leaders and students. The researcher used purposive sampling to carry out the study in ten sub-counties. This gave a total of 621 students, 120 teachers, 60 principals, 5 Islamic leaders, 10 church leaders, 2 County Directors of Education, 4 Education Officers and 1 curriculum developer. This gave a sample size of 823 respondents. The instruments for data collection were questionnaires for principals, teachers, students and interview schedule for religious leaders as well as education officers. Focus Group Discussion and Observation Schedule were also used. The instruments for data collection were assessed by curriculum experts. The questionnaires were piloted before going to the field. Presentation of data was put in tables, bargraphs, pie-charts and descriptions. The findings were as follows: religious organizations have been involved in implementation of curriculum activities. Unfortunately some cause divisions in the schools they sponsor by recommending unnecessary transfer of teachers and principals. The researcher also found out that parents, local communities and the Government of Kenya still play a crucial role in curriculum implementation. From the above findings the conclusion made was that, 
INTERNATIONAL JOURNAL OF ACADEMIC RESEARCH IN BUSINESS AND SOCIAL SCIENCES

Vol. 10, No. 7, July, 2020, E-ISSN: 2222-6990 @ 2020 HRMARS

the policy guideline given to religious organizations is not strong enough to allow religious organizations to be actively involved in implementation of curriculum. It was therefore recommended that there should be clear and strong policy guidelines on the role of religious organizations in curriculum implementation activities in public secondary schools.

Keywords: Curriculum, Religious Organizations, Involvement, Curriculum Implementation.

\section{Introduction}

Curriculum is a fairly new discipline compared to other fields of study in education. Marcia (1965) defines curriculum as presented content. Bishop (1995) defines curriculum as the sum total of experiences a learner undergoes. Curriculum is the vehicle for achieving the educational goals and objectives. Coming to the broader definitions of curriculum educators use the term curriculum to refer to various activities which involve teachers, school learners or even the community around. They include Blooms three domains of education and all subjects that a school offers to the learners and the organization of the subject matter and activities within a course or a unit offered by the school. Curriculum therefore becomes all that is planned to enable the students acquire and develop the desired knowledge, skills and attitudes. Ryan \& Cooper, (1998) defined curriculum as all organized and intended experiences of the student for which the school accepts responsibility.

Curriculum implementation is a systematic process of ensuring that the new curriculum reaches the intended consumers. Shiundu \& Omulando, (1992) view it as making real of what has been planned. It is worth noting that although a curriculum might be excellent, its proper implementation in the school system is not automatically guaranteed (Lewvy, 1997). Poor implementation can cause serious economic, psychological and social confusion in society. This is because a curriculum project is costly and if its implementation fails then the resources that could have been used in other sectors are lost. People may resist the implementation because it may disrupt status quo in the society. System training and system testing are the two initial strategies of the implementation phase of systems operation, (Banathy, 1968). If installation is decided upon, the system is put into operation in its planned environment. During operation, the system is continuously evaluated in order to measure its adequacy and the cumulative and terminal performance of the learner. It calls for changing the attitudes of stakeholders so that they can accept the new curriculum; this can be done through seminars, workshops and the mass media. The general public needs to be informed of the chances of: what, where, when, why and how of the curriculum. Educating or training the teachers through pre-service, in-service, seminars and conference is a vital process in curriculum implementation. Curriculum implementation without the provision of necessary facilities such as buildings, land, textbooks, toilets, libraries, water and laboratories would turn out to be an exercise in futility. Actual presentation of the new curriculum must be done through school timetables, safety guides and rules. Otunga, (2015) observes that there are demands upon those involved in the management of implementation which include considerable organization which have far reaching financial implications. This implies that the Government of Kenya has the duty of releasing enough funds on time for curriculum implementation.

Planners of curriculum need to ensure that there are right numbers of people in the right places for the curriculum to be appropriately implemented. These include the right number of trained teachers in schools, adequately prepared school principals, the right quality and quantity of curriculum 
supervisors as well as support personnel. The planners also need to ensure that the school buildings, furniture, equipment and materials are available in the right quality and quantities for appropriate implementation. Monitoring the implementation should be done in order to ensure that the curriculum implemented is as envisaged by its planners (Oluoch, 1984). Any curriculum or instructional plan must have an evaluation component (Otunga, 2015).

Curriculum implementation must focus on the three dimensions, that is, formal dimension, nonformal dimension and informal dimension. The formal dimension comprises the regular school subjects prescribed in the syllabus and presented to various class levels based mainly on age. Some of the subjects include: Mathematics, English, Geography, Biology, Physical Education, Kiswahili, Religious Education and others. (Bishop, 1995).The non-formal dimension of curriculum refers to organized learning activities or programs not restricted to any class level and which do not usually appear in the written syllabus, but contribute significantly to the achievement of educational aims. These learning activities were traditionally referred to as "extra-curricula" or "co-curricula" activities as if they were unimportant part of the school program. Informal curriculum refers to what some curriculum scholars call the "hidden curriculum". The hidden curriculum refers to some of the outcomes or by-products of schools or non-school settings, particularly those which are learned but not openly intended (Olouch, 1982). It is abroad category that includes all of the sometimes unintended knowledge, values, and beliefs that are part of the learning process in schools and classrooms.

Religious organizations in many countries are strongly involved in the implementation of curriculum in schools (Halls, 1990). In some countries such as Arabia, Israel, Iran, Ireland, Afghanistan and the like, religion plays many roles in education. It determines what should be included in the syllabus. In the Kenyan situation, religious organizations play many roles in schools. Religious organizations such as Catholic Church, Friends Church, Islam and Seventh Day Adventist, sponsor schools by participating in their physical development (Duke, 1990). They also help the government in designing the syllabus especially religious subjects which include Christian Religious Education, Islamic Religious Education, and Hindu Religious Education.

To put the research topic into perspective, one needs to find out the involvement of religious organizations in education from ancient times till the present time. The education system in Egypt around $4000 \mathrm{BC}$ aimed at achieving proper understanding of their religion and development of vocational skills. Egyptians had a nature religion which was cyclic. The ancient Egyptian education aimed at imparting skills which were necessary for the development and improvement of agriculture. The people of Egypt needed to develop adequate knowledge of Survey, Geography, Physics and Geometry for the measurement and maneuvering the flow of the waters of River Nile. The Nile has always been the lifeline of Egyptians. This river is sacred to the Egyptians. In Egypt education and religion were inseparable.

Unlike Christianity, the Greek religious education was based on the naturalistic spirit. They believed that life is to be enjoyed to the full. There were gods associated with love, war, death, and so forth. At the same time, limitation came in, based on the fact that the finite was good, but the finite was 
INTERNATIONAL JOURNAL OF ACADEMIC RESEARCH IN BUSINESS AND SOCIAL SCIENCES

Vol. 10, No. 7, July, 2020, E-ISSN: 2222-6990 @ 2020 HRMARS

regarded as the principles of the evil. The ancient city of Athens produced some of the best philosophers in the world who in turn had great influence on education.

Hebrew education was mainly by apprenticeship. This was the method used to bring up the youth in the Israel society up to the period of exile in 586 BC. As observed by Kimengi \& Lummalas (2009), the boys were inducted to the laws of the land from about the age of three and by the time the boys attained the age of thirteen they were expected to be fully conversant with the Torah (Mosaic Law) and be able to act in accordance with the teachings of these laws. The boys were expected to have mastered the religious ceremonies such as the rites relating to Passover, Atonement and Pentecost feasts. The Jews maintained God-centered rather than what they viewed as man-centered learning. To the Jews of the classical times religion meant personal loyalty to a jealous God. At the same time it was the key to knowledge and wisdom. The Jews believed in the following dictums: that all wisdom comes from the Lord and is with him forever, that the word of God, the most high is the foundation of wisdom and the fear of the Lord is a crown of wisdom. To the Jews therefore, religion provided the aim, it established the curriculum and dictated the methods of teaching. The girls however were excluded from learning the Mosaic Law

The ancient Hindu religion prepared one for life after death through education. Through education and religion, the Hindus reinforced and maintained the caste system in their society. This was based on the theory of reincarnation (Kimengi \& Lummalas, 2009). Hindus educational ideals were severe. A learner had to obey and follow the instructions of the teacher to the letter. In fact discipline was reinforced through corporal punishment.

Different kinds of schools were established during the Hindu classical period. They included: Parish schools which were assembly centers for the Hindu Priests (Brahmins), tutorial centers which were rooms for one learner and one teacher, forest colleges where teaching centered on the virtues of contemplation, and temple schools, where instructions mainly focused on religion and court schools which taught secular knowledge. These centers were actually universities established specifically for the Brahmins. Some of these notable Brahmins included, Benavers, Nadia, and Taksasila. Some of the subjects taught at these centers included natural and physical sciences, logic, literature, philosophy and religion. Hindu religion and life were interwoven.

The Chinese education of classical times concerned itself with human relationships, order, duty and morality. The greatest of the Chinese philosophers was Confucius who lived between 557-479BC. In a nutshell the Chinese schools taught respect for the aged as well as superior achievement. Confucius underscored the fact that states could only prosper when the final piety prevails and when a system of etiquette governs the social lives of people. The aim of Chinese education emphasized moving the world from the past to the present. There were three stages in the Chinese education system. These were: art of writing and literature, study of nine sacred books and study of philosophy and moral ideas. More emphasis was placed on discipline in the Chinese education system.

Christianity, the largest of the world's religions was born in the Graeco-Roman world. At the outset, it appeared to be a sect of Judaism, but it took its distinctive character from the fact that it centered in Jesus Christ. He rose from the dead after three days and he was proclaimed Lord and Savior by his 
INTERNATIONAL JOURNAL OF ACADEMIC RESEARCH IN BUSINESS AND SOCIAL SCIENCES Vol. 10, No. 7, July, 2020, E-ISSN: 2222-6990 @ 2020 HRMARS

followers. After receiving the Holy Spirit, the disciples of Jesus were inspired to spread the gospel far and wide, notable disciple being Paul who was previously called Saul.

Medieval time is a period which is also referred to as the "Dark Ages" of the Middle Ages. This is a period in history whose time is given as between $3^{\text {rd }}$ century A.D. and $12^{\text {th }}$ century AD. This period was characterized by global, social and intellectual stagnation. This was the period of conservation of knowledge. It was marked by the destruction of all that had been achieved by the classical civilization, hence the title "The Dark Ages".

During the" Dark Ages" two different forces precipitated the destruction, which occurred. These were: the growth of Christian supremacy, mysticism and supernaturalism, and the invasion by the Barbarians from the North. Secular teachings established by the ancient standards of education were viewed by the church as heathen and pagan hence had to be destroyed. The church schools were directed exclusively at the ecclesiastical objectives. This means that their teachings or curriculum was directed at the church doctrines only.

By $11^{\text {th }}$ century $A D$, the church had established a wide range of schools with the help of secular leaders. Some of the schools were monasteries which housed persecuted believers. They were located in the forests, mountains and caves. Convents were for women. Girls were accepted in convents at the age of six or seven, and were taught reading and writing. These girls later became nuns. The song schools were developed during the rule of Pope Gregory the Great (540 - 604AD). The main objective of the schools was to produce choristers during the celebration of mass in the church.

The Renaissance era began in Florence, Italy and spread rapidly to other Italian cities and the rest of Europe. Renaissance is a term used to refer to a period in history which lies between $13^{\text {th }}$ and $16^{\text {th }}$ centuries. During this period Europe experienced a re-birth of classical knowledge. The factors out of which the period of renaissance emerged included: the emergence and development of national languages and literature, the enrichment of cities, the expansion of commerce and industry, the rise of guilds, exploration, discoveries and inventions. The new scientific views were ridiculed at first and all those who were behind these ideas were persecuted. Well known names in connection with the geocentric views on the universe were Galileo and Newton. During this period people were more interested in human than divine affairs. There was renewed interest in classical literature and philosophy. Many schools in Europe came up during this period.

The Reformation period saw great changes take place in the Catholic Church. There was change or reconstruction within the society in terms of politics, religion and way of thinking. The brain child of Reformation was a German monk Professor called Martin Luther (1483 - 1546 AD The first and notable contribution which Martin Luther made to education was the translation of the Bible into German. The Bible soon became the national textbook. As a scholar, Luther maintained that schools should be governed by the state and not by the church. In all, inspiration to him was the best method for education

Formal education in America did not develop overnight into the current system (Cooper and Ryan, 1998). The system as we know it has its roots in the social, economic, political and religious history of the nation. Education in colonial America was originally religious in orientation but differed in form according to geographical area. Schooling in the colonial America was not available to women and 
children of color. However during the $19^{\text {th }}$ century free public education became a reality to many Americans. This was because of the ideas of men such as Jefferson, Benjamin Franklin, Horace Mann, Abraham Lincoln and others. The American civil war (1861 - 1865 AD) changed the perception of education in America. Education was now for all Americans, whites and those of color.

According to the First Amendment of the Constitution of the USA, Congress shall make no law respecting an establishment of religion or prohibiting the free exercise thereof (Ryan and Cooper, 1998). The American education in the past, 350 years has therefore been shaped and energized by six major themes. These are: local control through school boards, universal education which was generally available to all who actively seek it, public education which is publicly supported and compulsory, comprehensive education which demands the people to be educated through training for trades and preparation for college, secular education and lastly religious education which has remained in private schools.

Formal non-indigenous education in Kenya and indeed the whole of East Africa was brought by Arabs and Persians from the $7^{\text {th }}$ century AD. The aim of Muslim education was to study the Islamic law (Sharia) which was regarded as the only subject of true learning. Islamic education inculcated three main things in Muslim youth: belief in Allah (God) who, according to the Koran is the beginning and the end, have faith in Prophet Mohammed and lastly strong belief that all human activities should follow in the way of Allah.

During the colonial period in Kenya, Ismails opened eight schools at Kisumu (1921); Asembo Bay (1921); Kisii (1926); Hamud (1926); Kendu Bay (1928); Sio Port (1928). Between 1939 and 1946 nursery schools were opened in Mombasa and Nairobi by the Agha Khan Ismail community and in 1954 a primary school was built along Limuru road was built. Between 1932 and 1964 Ismails had opened 14 new schools in places such as Voi (1932 and 1942); Malindi (1933); Kimilili (1938); Nambale (1940s); Broderisk falls (1940s); Kadimu (1940s); Mwatate (1941); Kisumu (1948); Mombasa (1958) ; Nairobi (1964). After independence a number of secondary schools were opened in major towns in Kenya by the Agha Khan Islamic community.

At independence Islamic schools were mainly religious, and rote learning was at times done at the expense of understanding the message. Indeed, Muslim education did not permit complete freedom of choice for man in society. It discouraged pragmatism aimed at regulating rather than regimenting the activities of man as an expression of freewill. Indeed the dependence on Koran and perpetual reference to the past destroyed almost all initiative, creativity, originality and independence of Muslim mind. Illiteracy or the rate of lapsing to it was very high because majority of the youth did not go beyond six years of formal education (Bogonko, 1992).

According to Eshiwani (1993), Africans had an education system even before the coming of Europeans. This was Traditional African Education, the main goal of which was to train individuals to fit in their societies as useful members. It provided knowledge, skills and values relevant to society. It should be noted that education, religion and general way of life were interwoven. The climax of traditional African Education was during the rites of initiation such as naming, circumcision, marriage and death.

Formal curriculum was introduced in Kenya by Christian missionaries from Europe. The first mission school was established in 1847AD at Rabai near Mombasa. The first major aim of this curriculum was 
to produce African priests to spread the word of God. Africans were to be enlightened so that they could read the Bible. They were taught to read and write so that they could easily communicate with the missionaries. Other important aims of missionary education included, to impart Africans with relevant agricultural and manual skills and to improve their industrial knowledge. The completion of the Uganda Railway opened up East Africa and Kenya in particular to colonialists, missionaries and later educationalists and consequently raising further the profile of education in Kenya. According to Bogonko (1992) the Church Missionary Society founded Frere Town, which was to serve as a colony for freed slaves across the Mombasa Island. This was after the signing of the Frere Treaty of 1873 between Sir Bartle Frère and Said Burgash of Zanzibar. Out of Frère town and other communities of ex-slaves, came Kenya's first schools, the first African teachers and evangelists and in 1895, the first ordained ministers.

In the mean time, missionaries began asking themselves the question: How can the Gospel be spread most effectively? The freed - slave colony phase was over. In 1902, Hotchkiss returned to Kaimosi with Friends African Industrial Mission, for he had come to believe that evangelism alone was not enough. He wanted to introduce practical training, teaching men to be carpenters, brick makers and farmers. A Church Missionary Society (CMS) Missionary, Willis had another method. At Maseno School he introduced elite education. He invited Chiefs in the surrounding region to send their sons to the new school but only the dispossessed and unwanted boys were sent. Fifteen years later the traditional chiefs discovered that Willis disciples were displacing them. In every mission station, there was a school, a church and dispensary. Around the year 1915 many parents began to send their children to protestant churches and schools. After 1920, the demand for schools became acute and attendance became more regular (Barret et al, 1973).

Christians in the inter-tribal schools like Maseno School, Alliance High School and Buxton School, learned to understand and appreciate persons of other tribes. In a way, such schools promoted national cohesion. It would therefore not be wrong to assert that historically, the Christian missionaries have played a leading part in the development of education in Kenya. It was Christian missionaries who set up the first secondary schools. The first secondary school in colonial Kenya was Alliance High School established in 1926 by an Alliance of the Protestant Missions. The Catholic Church responded by creating Mangu School in 1928.

\section{Statement of the Problem}

Religious organizations have significantly influenced man's history and literature. This follows that a relevant curriculum must be dynamic and be able to satisfy the formal, informal, non-formal and moral development of the society as well as prepare its members for the opportunities, responsibilities and experiences of life. Religious organizations, making submissions to the Ominde Commission on Education- Republic of Kenya (1964), observed that an education system is one - sided unless the spiritual, values and standards of religion inform it. Religious sponsors of schools are expected to take care of the spiritual and moral development of the schools they sponsor. The Education Act (1968) legalized religious organizations and churches as sponsors of schools. The influence of religious organizations in implementation of secondary school curriculum in Kenya has however continued to draw mixed reactions from Kenyans. There are perceptions that religious organizations which sponsor schools have generally failed in their role as sponsors of public 
secondary schools because they do interfere in the management of schools. Moreover their role is not very clear and strong in the schools they serve. This affects curriculum implementation in schools. There are however those Kenyans who feel that the contribution of some religious organizations has been significant in curriculum implementation.

The Education Act (1968) provided for sponsorship of schools. It gave religious organizations an opportunity to be involved in the running of their respective schools. There are schools which do not have a mutual relationship with their respective religious organizations because they believe there is interference from the sponsor which causes conflicts with school management and implementation of the curriculum. Religious Organizations were expected to take care of spiritual, pastoral as well as moral needs of their clients. However, their operations were expected to be within the dictates of legal and policy framework. Today, a number of schools do not have enough facilities and chaplaincy services in spite of the heavy presence of religious organizations in the study area. Former Western Province has so many religious organizations. It is against this background that the researcher carried out a study in former Western Province in order to establish the role of religious organizations on curriculum implementation in public secondary schools.

\section{Methodology}

The study adopted a descriptive survey design since it dealt with a broad area of data collection. According to Bell (1999) a descriptive survey will aim to obtain information from a representative selection of the population, and from that sample one will then be able to present the findings as being representative of the population as a whole. According to Babbie (1992), survey research is probably the best method available to the social scientists interested in collecting original data for describing a population too large to observe directly. It also looks at relationships that exist among the variables in the field. On the other hand, Brinker (1988), Kothari(2004) do say that survey research is a method that involves asking relatively large number of people with the same set of standardized questions. The study was conducted in public secondary schools in former Western Province of Kenya. The religious organizations in the study area included: Roman Catholic Church, Friends Church, Salvation Army, Anglican Church of Kenya, Pentecostal Assemblies of God, African Divine Church, Apostolic Church, Israel Church of Nineveh, and Islam among others.

The sample for this study was: two county directors of education, four education officers, sixty principals of public secondary schools, one hundred and twenty high school teachers, six hundred and twenty one students, fifteen religious leaders and one curriculum developer. Form three students were particularly selected to participate in the study because they had already selected their subjects for KCSE and were available for the study unlike the form four students who were said to be busy with their studies.

Purposive sampling, structured and random sampling techniques were used in this study. According to Kerlinger (1983), Potton (1990) and, Orodho (2004), purposive sampling is used when there exist reasons to limit the sample to the cases that are likely to be information rich or respondents who are believed to be reliable for the study.

\section{Findings and Results}

The research was carried in four counties of former Western province of Kenya. The demographic characteristics were as shown in in the table below: 
INTERNATIONAL JOURNAL OF ACADEMIC RESEARCH IN BUSINESS AND SOCIAL SCIENCES Vol. 10, No. 7, July, 2020, E-ISSN: 2222-6990 @ 2020 HRMARS

Table 1 Distribution of schools and teachers per county in the study area

\begin{tabular}{lcccc}
\hline County & Schools & \% & Teachers & \% \\
\hline Bungoma & 10 & 16.7 & 22 & 18.3 \\
Busia & 5 & 8.3 & 16 & 13.3 \\
Kakamega & 25 & 41.7 & 45 & 37.5 \\
Vihiga & 20 & 33.3 & 37 & 30.8 \\
\hline Total & $\mathbf{6 0}$ & $\mathbf{1 0 0}$ & $\mathbf{1 2 0}$ & $\mathbf{1 0 0}$ \\
\hline
\end{tabular}

Information in Table 1 gives distribution of schools and teachers per county in the study region. It is clear from the table that, Vihiga County and Kakamega County had the highest number of participants in the study. This is attributed to many religious organizations in the area. Though small, Vihiga County has many religious organizations some of which serve as sponsors to the public secondary schools in the study area. The two counties: Kakamega and Vihiga, are among the most religious in the country. They both have mainstream churches and splinter groups.

Table 2: Distribution of Students in Various Schools in the Study Area

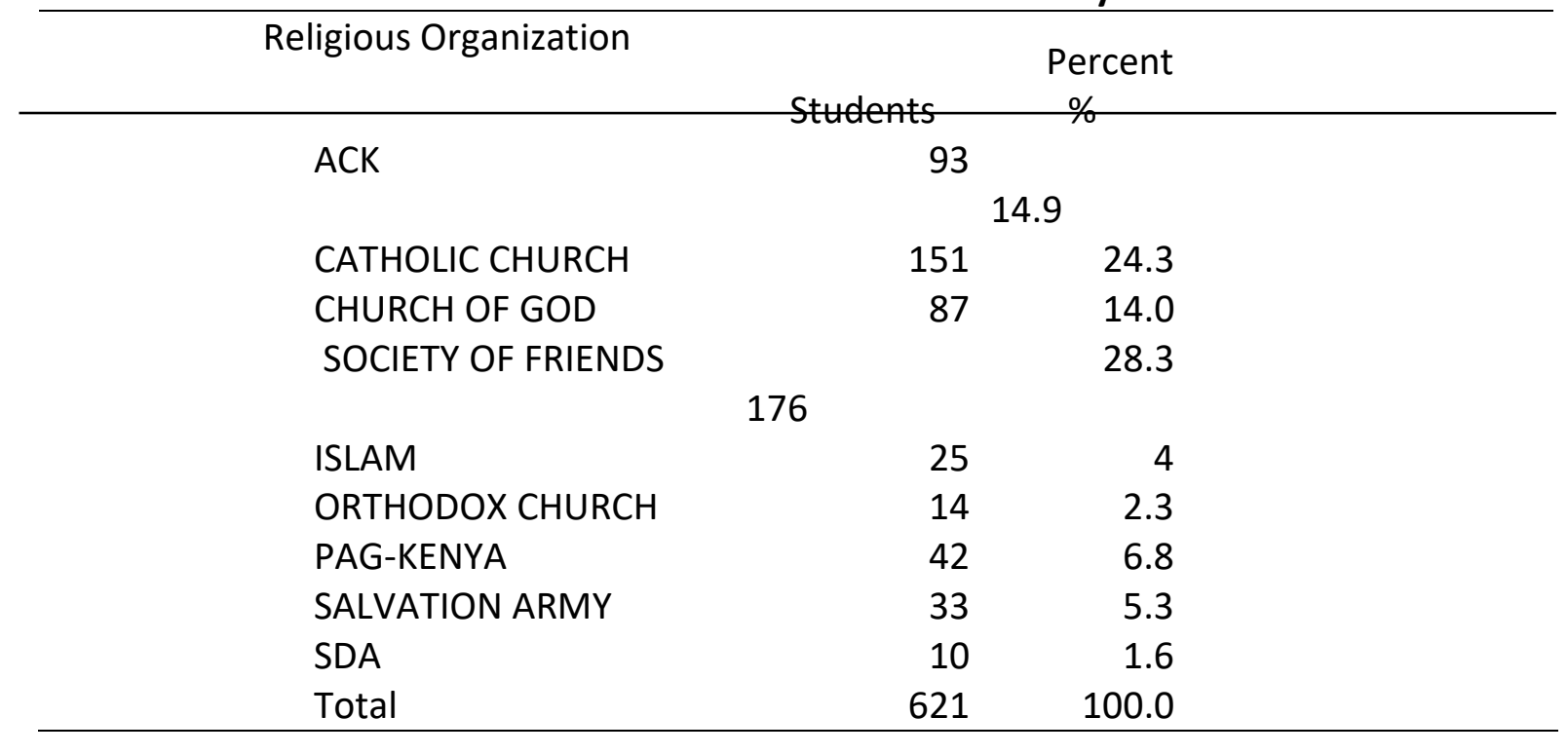

Data in Table 2 show that Friends Church at a figure of 176 (28.3\%), has more influence in the region because of the numerical strength of the students. It is closely followed by the Catholic Church at 151 (24.3\%). Dominance of Friends and Catholic Churches can be attributed to their early presence in the region. Both churches established their first mission stations in the area before 1914. In Catholic sponsored schools all students must attend mass regardless of their religious affiliation The Seventh Day Adventist has not yet penetrated the region. Perhaps this explains why they have few SDA students who participated in the study, few churches and schools as well. Because of their dominance and numbers in the region, the two religious organizations sometimes fail to recognize other religious groups. Islamic religion is majorly found in the urban centers. Most of the early Muslim missionaries preferred urban centers because of security and trade related reasons. On the other hand the Orthodox Church seems to sponsor the least number of schools in former Western province, with 14 respondents which translate to $2.3 \%$. 
INTERNATIONAL JOURNAL OF ACADEMIC RESEARCH IN BUSINESS AND SOCIAL SCIENCES Vol. 10, No. 7, July, 2020, E-ISSN: 2222-6990 @ 2020 HRMARS

\section{Involvement of Religious Organizations in Curriculum Activities}

The objective of study was to find out ways in which religious organizations are involved in school curriculum activities in public secondary activities in the study area. This objective addresses activities such as human resource management, guidance and counseling, curriculum development, provision of resources, formal and non-formal curriculum activities, staffing of teachers, subject combination of teachers, publishing and seminars for teachers among others.

\section{Human Resource Management}

Teachers who study at Diploma and Degree levels in Kenya must train in two academic subjects and professional courses (Shiundu \& Omulando, 1992). Some universities expect their students to major in two subjects from the beginning of the course up to the end while others expect their students to major in one subject in their final year of study. The Teachers Service Commission insists that for a teacher to teach in secondary school he/she must be competent in two subjects. Additionally, they must be equipped with the right pedagogical skills that are both heuristic and expository (Mutsotso \& Harper, 2009), Nasibi, 2003). In his contribution on school attachment which is mandatory for teacher trainees, Mutsotso as quoted in Otunga (2015) observes that hands-on teachers need to be well grounded, receptive and positive towards professional engagements. He goes further to say that a positive self-esteem is an important subset of the context for the success of training. In fact absence of feelings of self-worth and well-being will automatically lead to a person who is less confident and therefore not a career teacher. The researcher found that none of the Religious Organizations has established a diploma or university to train teachers in various subjects that are offered at secondary school level. This is an endeavor they should seriously consider in order to boost curriculum activities.

Table 3: Curriculum implementation as per subject combination of teachers

\section{Subject Combination}

\begin{tabular}{lrc} 
& Teachers & Percentage \\
& & \\
CRE/HOMESCIENCE & 3 & 2.5 \\
ENG/CRE & 3 & 2.5 \\
KISW/CRE & 37 & 30.8 \\
KISW/HIST & 10 & 8.3 \\
BUSINESS & 3 & 2.5 \\
STUDIES/CRE & & \\
HIST/ISLAM & 5 & 4.2 \\
ENG/IRE & 2 & 1.7 \\
HIST/CRE & 39 & 32.5 \\
GEO/CRE & 18 & 15 \\
Total & 120 & $\mathbf{1 0 0 . 0}$ \\
\hline
\end{tabular}

Data in Table 3 above show that 39 (32.5\%) of the teachers have a History/CRE combination in the study region. It was closely followed by Kiswahili/CRE combination with 37 (30.8\%) A total of 18 teachers (15\%) do teach Geography and CRE. Many of these teachers are in their forties and were 
INTERNATIONAL JOURNAL OF ACADEMIC RESEARCH IN BUSINESS AND SOCIAL SCIENCES Vol. 10, No. 7, July, 2020, E-ISSN: 2222-6990 @ 2020 HRMARS

trained at Kenyatta University, Moi University and the University of Nairobi. They trained in two teaching subjects.

The teachers also had their comments on what religious organizations have done in public secondary schools and they were captured in the figure below.

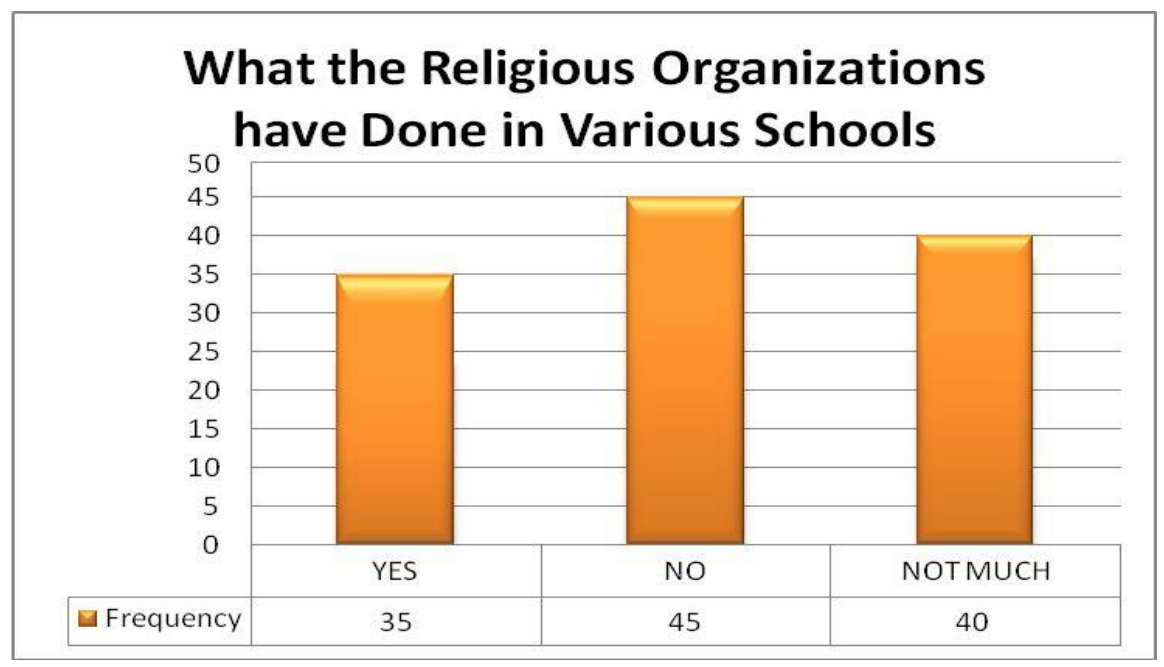

Figure 1: Contributions of religious organizations in curriculum activities

Results in Figure 1 shows that apart from the catholic sponsored schools, other religious organizations should go an extra mile and do alot for their schools. A total of 40 (33.3\% of teachers are of the view that the sponsor has not done much, while 45 (37.5\%) said that the sponsor has done nothing. Further more, only 35 teachers (29.2\%) said that religious organizations are involved in curriculum activities. This is a big challenge to the sponsors to be more actively involved in tangible development of their schools. The specifics of their involvement in varies curriculum activities is captured below.

Religious organizations do recognize the fact that the formative years spent in school by youths do establish the foundation of their lives on sound human and religious values. Based on this fact religious organizations remain a major partner and collaborate with the government of Kenya not only in implementing curriculum but in shaping the character of the youth as well. In some of the established boarding schools, guidance and counseling departments do a lot of work in guiding and counseling students. They work closely with school chaplains.

Many teachers do believe that religious organizations have a role to play in the implementation of curriculum. A total of 71 teachers (69.5\%) are of the opinion that schools cannot do without religious organizations. Some of the reasons advanced in support of religious organizations are they are experts in moral and ethical issues. Apart from the above they give spiritual nourishment to the learners. They also, guide and counsel students on a number of issues affecting them.

As noted in table 4 below, not so many teachers are involved in publishing of curriculum related materials. Religious Organizations should assist teachers who want to publish books for secondary school learners. 
INTERNATIONAL JOURNAL OF ACADEMIC RESEARCH IN BUSINESS AND SOCIAL SCIENCES Vol. 10, No. 7, July, 2020, E-ISSN: 2222-6990 @ 2020 HRMARS

Table 4: Involvement of teachers in curriculum development

\begin{tabular}{ccc}
\hline Response & Frequency & Percent \\
\hline Do & 20 & 16.7 \\
develo & & \\
$\mathrm{p}$ & & \\
Do not & & \\
develo & & \\
$\mathrm{p}$ & 100 & 83.3 \\
\hline Total & 120 & 100.0 \\
\hline
\end{tabular}

Results in Table 4 reveal that a small fraction 20, (16.7\%) of the teachers interviewed are involved in writing books in conjunction with Kenya Institute of Curriculum Development. Teachers should not just be mere implementers of syllabus but should also be actively involved in the development of the content. This in itself will ultimately make teachers feel that they own the curriculum and will therefore handle it confidently. Religious organizations should support this effort.

As concerns one's faith verbal interview carried with the teachers revealed that a teacher must not be a committed Christian or Muslim to teach in a given school. A big portion of teachers felt that commitment to ones faith does not translate into better examination results or a better teacher. Many teachers are of the view that what really matters is the professional commitment, competence and good morals.

Seminars and workshops are vital in the professional growth and development of a teacher. The sentiments of teachers on the same were captured in the figure below.

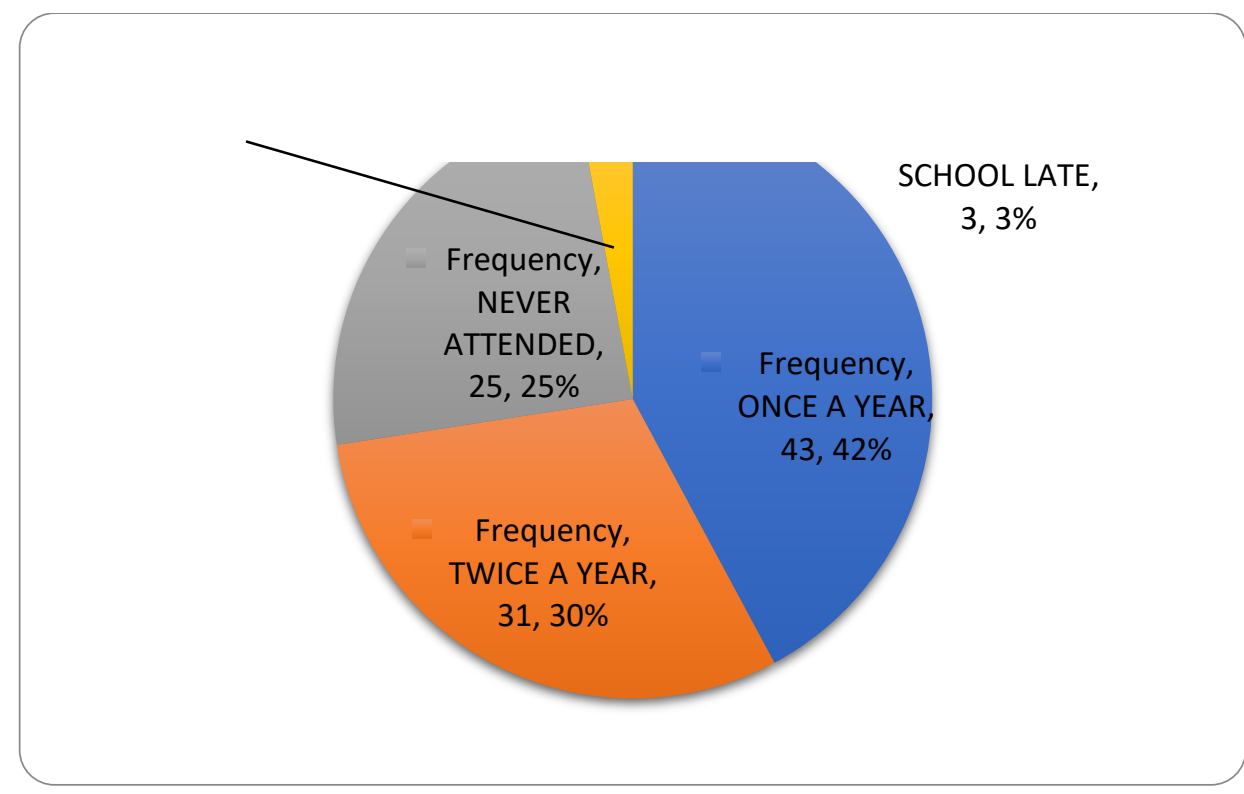

Figure 2: How often religious organizations organize seminars and workshops for teachers on curriculum issues 
Pre-service training introduces and inducts the teacher trainees on teaching profession but in service, seminars and workshops make the teachers better professionals which in turn enhance their performance (Malusu, 2007). The Gathachi report of the National Committee on Educational Objectives and Policies of (1976) emphasized the need for lifelong continuing education to all Kenyans. This was emphasized in the Master Plan on Education and Training of 1997-2010 as well as the Education Report (1999) that was chaired by David Koech. However it should be noted that further professional training of teachers should not be the responsibility of Government of Kenya alone.

Religious organizations should organize seminars and workshops for teachers so that teachers of various subjects can keep abreast with the latest curriculum changes in their subjects. Results from Figure 2 show that $50(42 \%)$ of teachers do agree that they have attended seminars and workshops once a year, 36 (30\% have attended twice a year while $30(25 \%)$ have never attended. It should be noted that workshops are not just important for teachers only but for the benefit of learners as well. As regards textbooks ratio, figure 3 revealed a lot of information concerning schools in the study area.

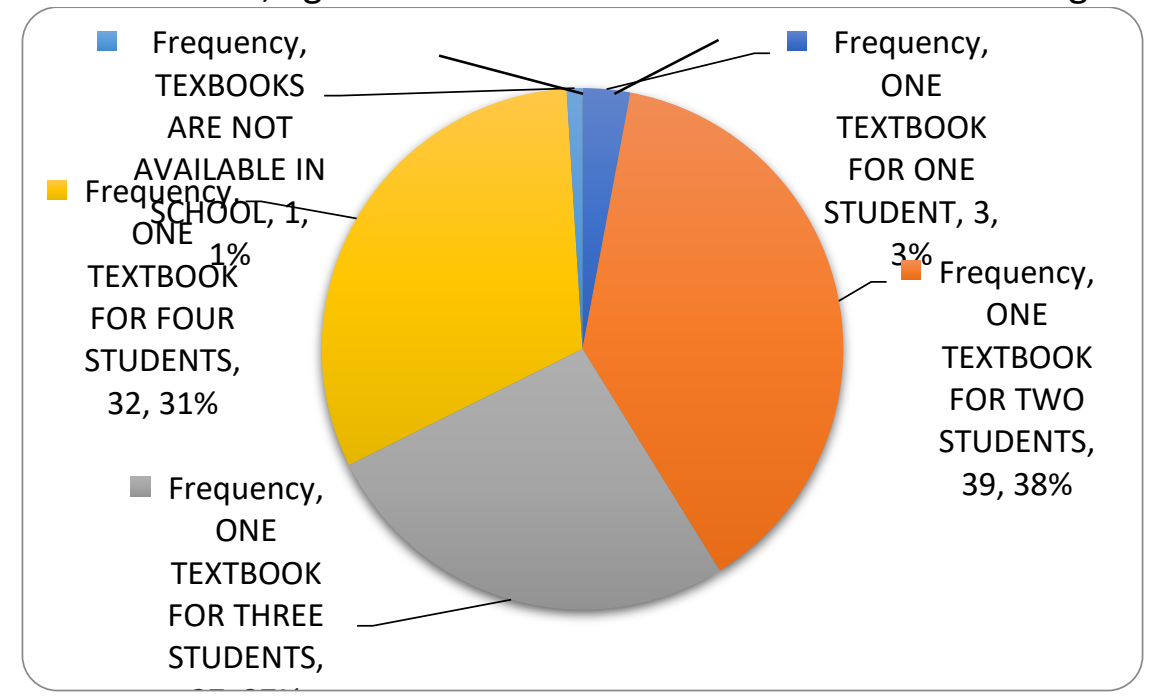

Figure 3: Influence of religious organizations in the provision of textbooks for curriculum implementation

Results from Figure 3 indicate that textbook ratio for students varies from one textbook for two students at $38 \%$, one textbook for three students at $27 \%$ and one textbook for four students at $31 \%$. The study further revealed that day schools are in a bad state as far as textbook ratio is concerned. Generally the textbook ratio was found to be very low in many schools. These findings concur with those of Ashioya, (2014) who found out that many schools had not attained the Ministry of Education projection of a textbook pupil ratio of 1;2. A number of established boarding schools have tried to avail textbooks to students. Schools that invest in recommended school textbooks normally perform well in national examinations. The printed word will always remain one of the best sources of reference and information. One of the teachers observed that recommended textbooks by the Ministry of Education are important in the life of students because many parents and schools cannot afford to buy computers and laptops for their children. Religious Organizations should therefore assist various schools in the provision of textbooks to improve learning and performance. Nothing has ever replaced the printed word as the key element in the educational process; hence textbooks 
INTERNATIONAL JOURNAL OF ACADEMIC RESEARCH IN BUSINESS AND SOCIAL SCIENCES Vol. 10, No. 7, July, 2020, E-ISSN: 2222-6990 @ 2020 HRMARS

are critical to schooling at all levels. Indeed for many teachers, textbooks do provide an excellent and useful resource without demeaning the authority of the teacher (Eshiwani, 1984). The printed word in textbooks remains one of the most important instructional materials in the teaching and learning process.

Through oral interviews done by the researcher it was established that the Catholic Church and the Church of God in East Africa do set mock examinations. For instance, the Church of God in East Africa, organizes a mock examination for its schools, while the Catholic Church sets a mock examination called Dioceasan for its secondary schools in Kakamega Diocese. The Catholic Church has also organised workshops for deputies and principles on school curriculum and management. Indeed this is a good step in boosting the performance of these schools in internal and national examinations. The Secretary General and the Education Secretary of Pentecostal Assemblies of God-Kenya, noted that the church had continued to sponsor secondary schools in the four counties. In addition, they have established three polytechniques, a bible training school, a leading boys school next to its Nyang'ori headquaters and a Teachers Training College at Goibei in Hamisi Sub-county. He further stated that besides spiritual guidance done by school chaplains in schools, the P.A.G church makes immense material and spiritual contributions. A few computers were donated to Nyang'ori Boys High School, Goibei Girls High School and Madira Girls Secondary School. The youth polytechnique and the bible school at Nyang' ori are fully sponsored by P.A.G. However students are charged subsidised fees so as to sustain their programmes. The P.A.G. Education Secretary said that a proposal had been written and sent to relevant authorities with a view to establishing a university that will offer degree courses in Arts, Education, Bussness Adminstration and Theology.

The Salvation Army Church has been organizing a joint examination for its schools in western Kenya. The examination is called: Salvation Army Kenya West Territory Examination Team (SAKWETET). The Salvation Church also buys trophies to encourage competition among students in its schools. One of the principals observed. It goes ahead to sponsor a few of the learners from humble backgrounds by paying their fees. Other than academic programmes some of the religious organizations have bought lockers for students, for instance, the Orthodox Church did so at Chavogore secondary school. The SDA Church bought hundreds of plastic chair for Chebwai Secondary school as well as renovating the school chapel and administration office. A leading Girls High School in Sabatia sub-county, has been bought for land, assisted in constructing school hostels and provided with water tanks by the Salvation Army Church in order to improve the learning environment.

At one of the biggest girls school in Vihiga sub-county, the Salvation Army bought seats for the school library, bibles, hymn books and water tanks. At another girls school, the Salvation Army Church bought water tanks and beds for domitories. However, most principals felt that various religious organisations have not done enough in terms of physical structure for their schools compared to what parents have done through Parents Association projects.

The Education Act ( RoK,2013) requires that Boards of Management of schools ensure smooth running of schools. Religious organisations through the sponsor handle topics such as: sex education, drug and alcohol abuse, spirituality, effects of radicalization among others. The Catholic Church wants family life education to be handled by parents and not teachers. This has been a source of conflict in many schools. 
INTERNATIONAL JOURNAL OF ACADEMIC RESEARCH IN BUSINESS AND SOCIAL SCIENCES Vol. 10, No. 7, July, 2020, E-ISSN: 2222-6990 @ 2020 HRMARS

Table 5: How often the sponsor speaks to the school community

\begin{tabular}{ccc}
\hline Visitation & Frequency & Percent \\
HAS NEVER VISITED & 96 & 15.5 \\
THE SCHOOL IN THE & & \\
LAST TWO TERMS & & \\
OFTEN & 209 & 33.7 \\
SOMETIMES & 237 & 38.2 \\
VERY OFTEN & 79 & 12.6
\end{tabular}

Total $\quad 621 \quad 100.0$

Based on responses from students in various schools results in Table 5 show that religious organizations that do visit schools were at $96(15.5 \%)$, while those who sometimes visit their schools were at $237(38.2 \%)$. A total of $209(33.7 \%)$ of the respondents they often visit their schools. It is important that religious organizations be close to their schools so that they can guide and counsel students and play an active role in the programs of their schools.

Table 6: Students views on the support of religious organizations in curriculum implementation through provision of resources

\begin{tabular}{|c|c|c|c|c|c|c|c|}
\hline RESOURCES & \multicolumn{6}{|c|}{$\begin{array}{l}\text { ACTIVITY } \\
\text { NOT }\end{array}$} & $\begin{array}{c}\text { TOTAL } \\
\text { NUMBER } \\
\text { INTERVIEWED }\end{array}$ \\
\hline Teachers & 461 & 74.3 & 151 & 24.4 & 9 & 1.2 & 621 \\
\hline Bible/Quran & 373 & 60.2 & 227 & 36.7 & 21 & 3.3 & 621 \\
\hline Computers & 227 & 36.6 & 383 & 61.8 & 11 & 1.7 & 621 \\
\hline $\begin{array}{l}\text { Resource persons from } \\
\text { community }\end{array}$ & 262 & 42.2 & 327 & 52.8 & 32 & 4.9 & 621 \\
\hline Chaplain & 476 & 76.7 & 135 & 21.8 & 10 & 1.5 & 621 \\
\hline Water tanks & 360 & 58.1 & 242 & 39.0 & 19 & 2.9 & 621 \\
\hline Youth seminars & 245 & 39.5 & 358 & 57.8 & 18 & 2.8 & 621 \\
\hline Icons/ Statues & 166 & 18.7 & 469 & 75.6 & 36 & 5.5 & 621 \\
\hline Textbooks & 416 & 67.0 & 193 & 31.2 & 12 & 1.8 & 621 \\
\hline $\begin{array}{l}\text { Library, Tables and } \\
\text { Chairs }\end{array}$ & 315 & 50.8 & 288 & 46.5 & 18 & 2.8 & 621 \\
\hline
\end{tabular}


INTERNATIONAL JOURNAL OF ACADEMIC RESEARCH IN BUSINESS AND SOCIAL SCIENCES Vol. 10, No. 7, July, 2020, E-ISSN: 2222-6990 @ 2020 HRMARS

Findings in Table 6 show that 373 (60.2\%) respondents said that religious organizations do provide Bibles and Qurans to their schools. The availability and use of teaching and learning resources in schools is ranked among the most influential factors which affect examination performance in secondary schools. A resource is any object or material that facilitates the teaching-learning process. The response of learners on whether computers are availed or not was as follows; a total of 227 (36.6\%) said that the sponsor had donated computers to their school while $388(61.8 \%)$ said that they do not have computers in their schools. According to Kevogo, (2014), computer application has mixed effects on instructional system depending on when they are used. He goes further to say that the computer application effects on academic achievement do not operate in isolation. However teachers need to guide students on computer use because students mainly use computers for playing games, listening to music, watching videos and browsing but rarely use them for making notes and research. Computer Technology cannot therefore be ignored in the modern world. A total of $327(52.8 \%)$ of the respondents observed that resources persons are not availed by religious organizations to their schools. Resource persons are vital because they break the monotony of the teacher in the classroom.

The library is an essential component in the teaching and learning process. A library is a building or a room in which collections of books, tapes, newspapers among other collections are kept for people to read, study or borrow. A good modern and equipped library enhances good learning and achievement of high educational standards. School libraries may not be effective if books therein are not adequate and up to date as its impact may only be meaningful if the library could be open to students always for a considerable length of time in a school day. The current study shows that $315(50.8 \%)$ of the respondents who participated in the study indicate that religious organizations have tried to equip libraries in the schools they sponsor. Some have donated chairs and tables while others have bought holly books especially Bibles and Quran. However in one of the schools, students complained that the library had become a multipurpose hall because it is used for staff meetings, Board of Management meetings, a dining room for dignitaries who visit the locality and a place where school supplies are kept before they are transferred to the central store. This must stop if the library is to serve its clients to their satisfaction.

Youth seminars are important because through them learners interact, network, socialize and learn a lot from others. Religious Organizations need to organize more youth seminars. Only 245(39.5\% of the respondents pointed out that religious organization do organize seminars for young people where they are guided and counseled, mentored and nourished spiritually.

Chaplaincy services are crucial for moral and spiritual development of learners. School chaplains also offer guidance and counseling services across the school spectrum. A total of $476(76.7 \%)$ of the respondents said that they have school chaplains in their schools that cater for their spiritual and moral needs. This is quite commendable considering the fact that young people are living in a fast changing world that requires a lot of guidance and informative answers to disturbing questions of life.

Icons, crucifix and statues were majorly found in Catholic Schools. Giordia (2015) observes that display of crucifix in Italian schools implies that it is a state symbol, a religious symbol, a universal symbol of tolerance and freedom as well as a cultural symbol. On the issue of provision of teachers of CRE/IRE learners may not be aware that majority of them are employed by Teachers Service Commission and Boards of Management of Schools. In a world where religious matters have become 
INTERNATIONAL JOURNAL OF ACADEMIC RESEARCH IN BUSINESS AND SOCIAL SCIENCES

Vol. 10, No. 7, July, 2020, E-ISSN: 2222-6990 @ 2020 HRMARS

very sensitive one is left wondering whether schools should openly display religious symbols and icons, This is because secondary schools in Kenya admit students from various cultural background.

\section{Conclusion}

The objective of study was to establish the involvement of religious organizations in curriculum implementation in public secondary schools in former Western province of Kenya. The study therefore found out that some religious organizations in the study region are directly involved in the implementation of curriculum activities in public secondary schools. For instance they are involved in: spiritual nourishment, chaplaincy in schools, guidance and counseling, setting of internal examinations, writing of syllabus for Religious Education books (CRE|IRE/HRE) in conjunction with Kenya Institute of Curriculum Development. The Catholic Church, Salvation Army and Church of God in East Africa are involved in curriculum activities through donation of computers, and organizing youth seminars. The donation of land by religious organizations is a factor that is appreciated by all stakeholders in education. Recently the President of the Republic of Kenya gave an ultimatum to the Ministry of Education to hand over all schools founded by religious organizations to the right full owners (Ondiek, 2018, Mathenge, 2018, Odour \& Kareithi, 2018). This has reignited an old debate between religious organizations and the Government of Kenya which currently is in charge of all public secondary schools following the enactment of several laws and policies regarding education since independence. The Education Act (RoK, 2013) gives religious organizations power to ensure the spiritual welfare of schools is catered for. Most education officers believe that the sponsors have not been given enough roles by the Education Act (RoK, 2013)

\section{Recommendations}

In view of the findings and conclusion, religious organizations should be more involved in the implementation of the curriculum and other related activities as stipulated in the Education Act (RoK, 2013). They should strengthen guidance and counseling departments by training teachers, carry out pastoral work, do spiritual nourishment and complement government efforts in implementation of curriculum in public secondary schools. For proper management of public schools in Western region of Kenya, religious organizations should nominate well educated and enlightened cadre of individuals to serve on the Board of Management (BOM) and also urge them to attend relevant meetings regularly. It is encouraging that some religious organizations such as Salvation Army, Church of God in East Africa and the Catholic Church do give mock examinations to the schools they sponsor. Other religious organizations in the region should emulate this good example.

\section{References}

Aggarwal, J. C. (2003). Principal Methods and Techniques of Teaching ( $2^{\text {nd }}$ ed) New Delhl: Vika Publishing House PVT Ltd.

Aduda, D. (2018). Balancing Act: Solving School Ownership Will Take More than Uhuru Directive. Nairobi: Sunday Nation, November 18, 2018 p. 5. Nation Media Group.

Amugune, A. A., Mutsotso, S. N., \& Shiundu, O. J. (2018), Origin and Development of Key Religious Organizations in Kenya: Their Influence on Curriculum Implementation in Public Secondary Schools. International Journal of Academic Research in Business and Social Sciences, Volume 8, Issue 6. 
INTERNATIONAL JOURNAL OF ACADEMIC RESEARCH IN BUSINESS AND SOCIAL SCIENCES

Vol. 10, No. 7, July, 2020, E-ISSN: 2222-6990 @ 2020 HRMARS

Babbie, E. (1998). The Practice of Social Research. London: Victoria Bonn.

Barasa, M. J. (2012). Influence of Professional Development of Teacher Effectiveness in Public

Secondary Schools in Mumias District. Unpublished M.Ed Thesis, Maseno University

Barasa, O. S. (2013). The Contribution of the Church Missionary Society to the Development of

Education: A Case of Ngiya Girls School of Siaya County, Kenya 1923-1967.

Becks, R. H. (1965). A Social History of Education. New Jersey: Prentice Hall, Inc. Englewood Cliffs.

Bebbie, C. E. (1996). Planning and Educational Administration Paris: IIEP UNESCO.

Bishop, G. (1995) Curriculum Development: A Textbook for Students. Hong Kong: Macmillan Education Ltd.

Bogonko, S. N. (1992). A History of Modern Education in Kenya (1895-1991). Nairobi: Evans Brothers (Kenya) Ltd.

Dale, E. (1954). Audio Visual Methods in Teaching. New York:The Drydgen Press.

Duke, D. L. (1990). Teaching: An Introduction. New York: McGraw - Hill Company. Ellington, H. and Percival, F. (1988). A Handbook of Educational Technology. $2^{\text {nd }}$ Edition. Boston: Allyn and Bacon Inc.

Eshiwani, G. S. (1984).Factors Influencing Performance among Primary and Secondary Students in Western Province. Nairobi: A policy Study Bureau of Education Research, Kenyatta University.

Eshiwani, G. S. (1993). Education in Kenya since Independence. Nairobi: East African Education Publishers.

Gisege, O. S. (2006). Role of Isukha Religious Beliefs and Practices in the Conservation of Kakamega Forest. Unpublished Thesis (M.A), Maseno University.

Government of Kenya, (2013). Basic Education Act, Nairobi: Government Printer.

Halls, W. D. (1990). Comparative Education: Contemporary Issues and Trends. London: Jessica Kingsley Publishers.

Harper, S. B. (2017). New Directions in Curriculum \& Instruction. Kakamega: Double Shasa.

Hull, J. M. (1984). Studies in Religion and Education. London and New York: The Falmer Press.

Jerry, A., \& Renitta, G. (2006). Current Laws and Trends in Education. Second Edition.

Pearson: Boston, New York, et-el.

Kakkar, S. B. (2004). Educational Psychology. New Delhi: PVT Ltd.

Kathuri, N. J., \& Pals, D. A. (1993). Introduction to Education Research, Egerton University: Educational Media Centre.

Kevogo, N. (2014). Impact of Computer Application on Learning and Achievement in Biology by Secondary Schools in Kenya. Unpublished Ph.D Thesis, Masinde Muliro University of Science and Technology.

Kilinger, F. N. (1983). Foundations of Behavioural Research. New York : Holt Reinhart and Winston Inc.

Kimange, I. N., \& Lummalas, J. E. S. (2009). History of Education A study of Historical Developments in Education Policies and Practice from Ancient to Modern Times. Moi University, Eldoret: Moi University Press. Kenya.

Kombo, D. K., \& Tromp, D. L. (2006). Proposal and Thesis Writing: An Introduction. Nairobi: Paulines Publication Africa.

Kothari, C. R. (2004). Research Methodology, Methods \& Techniques (2 ${ }^{\text {nd }}$ Edition). New Delhi. New Age International (P) Printers Ltd. 
INTERNATIONAL JOURNAL OF ACADEMIC RESEARCH IN BUSINESS AND SOCIAL SCIENCES

Vol. 10, No. 7, July, 2020, E-ISSN: 2222-6990 @ 2020 HRMARS

Kurgat, M. S. (2004). The Catholic Church and Social Change in Busia District, Kenya (1924-1995.) Unpublished PhD Thesis, Maseno University.

Mathenge, G. (2018). Church's Fight for Institutions has been Decades-Long Journey. Nairobi: Sunday Nation, November 18, 2018 p.5. Nation Media Group.

Mbiti, D. M. (1974). Foundation of Schools Administration. Nairobi, Oxford university Press.

Mutsotso, S. N., \& Harper, S. B. (2009). Establishing Heuristic Learning Process in the Classroom: The Implication for Pedagogical Strategies. Kenya Journal of Education Management, 3(2).

Oduor, A., \& Kareithi, A. (2018). Dilemma Deepens on Order to Hand Schools to Churches. Nairobi: Sunday Standard. November 18, p.2. Standar Media Group.

Ogada, O. J. (2012). Relationship between Availability and Utilization of Selected Learning Resources and Academic Performance in Public Secondary Schools in Kenya. Unpublished, M.Ed Thesis, Maseno University.

Oliver, R. (1966). The Missionary Factor in East Africa, London :Longmans Green and Co. Ltd

Oluoch, G. P. (1984). Essentials of Curriculum Development. Nairobi: Elimu Bookshop Ltd.

Ondieki, E. (2018). School Titles Transfer Process Needs Time. Nairobi: Sunday Nation, November 18, 2018 p.4. Nation Media Group.

Orodho, J. A. (2004). Techniques of Writing Research and Reports in Education and Social Sciences. Nairobi: Masola Publishers.

Otunga, N. R. (2015). Dynamism in Curriculum and Instruction. Eldoret : Utafiti Foundation.

Republic of Kenya. (2013). Basic Education Act. Narobi : Government Printers.

Simiyu, M. A. (2001). The Systems Approach to Teaching: A Handbook for Teachers.

Eldoret: Western Educational Publishers.

Shanguhyia, S. (1996). The Contribution to Education Development by PAG in Kenya. Nyang'ori school and its Impact1940-1973. Master of Philosophy in Education. Unpublished Thesis, Moi University.

Shiundu, J. O., \& Omulando S. O. (1992). Curriculum Theory and Practice in Kenya. Nairobi: Oxford University Press. 